\title{
Perspective
}

\section{"The art of scientific investigation" and "The logic of scientific inference"}

\author{
Arseculeratne $\mathrm{SN}^{1 *}$ \\ ${ }^{1}$ Emeritus Professor of Microbiology, Faculty of Medicine, University of Peradeniya
}

\begin{abstract}
The contemporary modes of "medical Education" in Sri Lankan faculties of medicine are briefly reviewed. What are missing are discussions on rational practice of scientific research including the use of proper controls, an understanding of the role of logical inference from research results, and a knowledge of the basic philosophy of modern science; this lack results in a state of scientific illiteracy that leads to misconceptions in the interpretation of research findings. A further desideratum is an awareness of the preceding, valid, published literature. Illustrations from the research literature are provided in illustration of the consequences of these deficiencies. None of the Sri Lankan universities, except the Open University as far as the author is aware, includes discussions on the Philosophy of Modern Science in their curricula.
\end{abstract}

Key words: Scientific investigation; Scientific inference; Scientist

Copyright: (C) 2013 Arseculeratne SN. This is an open access article distributed under the Creative Commons Attribution License, which permits unrestricted use, distribution, and reproduction in any medium, provided the original work is properly cited.

*Correspondence: $\underline{\text { chubby@sltnet.lk }}$

How to cite: Arseculeratne SN. "The art of scientific investigation" and "The logic of scientific inference". Anuradhapura Medical Journal 2013;7(1):15-17

DOI: http://dx.doi.org/10.4038/amj.v7i1.6138 
I am borrowing those titles from W. I. B. Beveridges's(1) and Jennifer Trusted's(2) useful books respectively, to make general comments on [i] the role of logical inference in the pursuit of scientific investigations and then, [ii] specifically, misconceptions on a disease that result from faulty education and practice in science and an absence of elementary ideas in the philosophy of modern science.

First, I will quote the opening lines from an essay in Scientific American titled, "Trust me, I am a scientist" by Daniel Willingham(3).

"A friend of mine has long held that a vaccination his son received as an infant triggered his child's autism.

He clings to this belief despite a string of scientific studies that show no link between autism and vaccines. When the original paper on such a link was recently discredited as a fraud, my friend's reaction was $b$ that it will now be difficult to persuade people of the dangers of vaccination".

That story illustrates the dangers that are faced by serious teachers and researchers in their attempts to establish a state of scientific literacy not only of the citizen, that I have earlier called Scientific Literacy for the Citizen SLC, but also of Scientific Literacy for the (Scientific) Elite, SLE(4). These dangers arise from modes of education in science that have gone awry.

The state of scientific illiteracy that results from faulty science-education is illustrated by the quagmire concerning Rhinosporidium sebeeri, the enigmatic organism that causes rhinosporidiosis in humans and animals, that we have been researching on for the last fifteen years.

Rhinosporidiosis was first observed by Malbran in Argentina in 1892. G. R. Seeber, also in Buenos Aires, Argentina described this disease and its causative organism, for his MD thesis in 1900(5). R. seeberi has never been cultured in the laboratory in vitro, nor has it established rhinosporidiosis when administered as suspensions of rhinosporidial tissue, to experimental animals. These two characteristics have made research and derivation of valid conclusions on this pathogen, extremely difficult, although it is readily observed by conventional histopathology in rhinosporidial tissues and was recently explored by molecular biological techniques by in situ hybridization with primers designed on its gene sequences, and with other molecular biological tools, through which definitive conclusions on its taxonomy and natural habitat, ground waters, were made(6)With these new techniques, $R$. seeberi was removed from the orphanage "Fungus- like organisms"(7) and placed in a new Clade, the Mesomycetozoea, by Herr et al.(8), supported by the findings of an independent group of researchers, Fredricks et al(9).

In 1992 and in 1994, Ahluwalia(10,11,12) and co-workers in India reported that the round body described as $R$. seeberi by earlier workers and fully described in the monograph Rhiniosporidiosis in Man by W. A. E. Karunaratne in 1964 is not a biological organism at all but lumps of tapioca starch in lysosomes that resulted from the excessive consumption of starch from tapioca (manioc, Manihot utilissima syn. esculenta). The same group of 'researchers', later recanted this view and then in 1997, incriminated the ubiquitous cyanobacterium Microcystis aeruginosa, found in ground waters, as the real cause of rhinosporidiosis. Their starch-conclusion was based on [a] morphological similarities based on the "round bodies", endospores and sporangia in $R$. seeberi and lysosomes in human cells, respectively, and [b] similarities on molecular biological findings (e.g. PCR bands) from extracts of rhinosporidial polyps on the one hand and from $M$. aeruginosa (that can be cultured in the laboratory) on the other.

Refutations of Ahluwalia's Microcystis-thesis were made by Arseculeratne(13) and by Mendoza et. al.(14) in the USA, on the grounds of [i] the absence of control samples from normal persons living in the same habitat-area from which their water samples were collected, [ii] improper collections of samples (from contaminated sites) for molecular biological tests, [iii] the inability of $M$. aeruginosa to cause rhinosporidiosis, [iv] the absence of reactivity of $M$. aeruginosa extracts with human patients' sera and experimental antisera containing high titres of anti-rhinosporidial antibody in immunodot-blot tests, and [v] the absence of amplification in PCR tests of $M$. aeruginosa extracts with primers based on sequences of $R$. seeberi. They attributed Ahluwalia's Microcystis-error to contamination by this water bacterium.

The error of incriminating starch and then $M$. aeruginosa arose not from the use of faulty technology but by the use of faulty inferences from the results obtained from the misapplication of faulty logic and by being seduced by sophisticated technology without the proper application of the principles of scientific inference; indeed I would use the term, Idola machinorum, the uncriticial, idolatrous application of sophisticated technology, akin to Idola quantitatis that Peter Medawar(15) used to describe the use of sophisticated mathematical, computer generated figures to cover the nakedness of faulty conclusions, just as much as if one looks at a leopard through a telescope, one sees just a spot and not the whole leopard. The first Ahluwaliaerror is also akin to the misapplication of the Aristotelian syllogism $\mathrm{A}=\mathrm{B}, \mathrm{B},=\mathrm{C}$, hence $\mathrm{A}$ must be equal to $\mathrm{C}(16)$ $R$. seeberi has round bodies, lysosomes containing starch are round bodies, ergo (therefore), R. seeberi is a starchbearing lysosome.

This error of making faulty inferences is also exemplified by the story of the old professor-zoologist who described his work on locomotion in fleas; he fished out a flea from his box, placed it on the lecture-table and yelled at it, "jump", and the flea did jump. The professor then removed the legs of the flea, one by one, and then shouted again "jump"; but the flea did not jump, whereupon the professor announced his discovery that "the flea hears through its legs". His observation that the flea without its legs did not jump is acceptable as valid, but not his conclusion that the flea hears through its legs, as the flea does not have a hearing-organ. He apparently was not aware that a flea will respond to vibrations that his yell "Jump" would have caused, and his conclusion was therefore bedevilled by his ignorance of the fact that the 
flea has no ears but is sensitive to vibrations. This illustrates another requirement for valid conclusions, that of awareness of the valid facts that have already been discovered through proper scientific methodology, i.e. familiarity with the scientific literature. Ahluwalia's first misinterpretation recalls that carbohydrate molecules are ubiquitous, being shared by plants and animals and their presence in species of both Kingdoms, plants and microbes, is not proof of the identity of the species, $R$. seeberi with $M$. aeruginosa. Their M. aeruginosahypothesis was born of faulty planning of investigations, in having used nasal rhinosporidial polyps with their rough, surfaces containing crypts (that are open to contamination by micro-organisms, including $M$. aeruginosa, in ground water), and not the lesions of disseminated rhinosporidiosis that remained covered by unbroken skin and which were therefore not exposed to aquatic $M$. aeruginosa in its natural habitat of ground water.That the starch and $M$. aeruginosa theories of Ahluwalia were published in socalled prestigious western journals, opens another can of worms - the role of proper refereeing and editorship of submissions by science-journals; this topic is, however, outside the scope of this essay.

These comments bring me to consider "The place of The Philosophy of Science in education in Science". The philosophy of science (that includes the art, and methodologies of scientific investigation, the use of proper controls, valid inferences, derivation of hypotheses, understanding the ideas of Causality, the formulation of theories, the falsification or verification of theories, the formulation of scientific laws) is, as far as I am aware, not discussed in Sri Lankan undergraduate curricula, except in the Open University, Colombo, which was entirely on the personal initiative of just one man, Professor Arjuna de Zoysa. It also reinforces my conviction(17) that it is the individual administrator of an institution rather than the institution's policy itself, that is of predominant importance, contrary to what our distinguished diplomat Mr. Jayantha Dhanapala argued; he had said: "I have long believed that the most durable achievements in public policy are best realized through institutions rather than individuals"

When I was given the task of administering the Centre for Research in Tropical Medicine at the Faculty of Medicine, University of Peradeniya, I intended starting with a series of lectures on The Philosophy of Science, whereupon a Senior Professor in the Peradeniya medical faculty asked me, "Of what use is the philosophy of Science?". I then asked ten young Ph.D's in our faculty "Why is your degree called a Doctorate in Philosophy?" - none knew. These young Ph.D's and the Senior Professor did not have a metaphorical leg to stand on, like the legless flea; I held my head in horror.Four centuries of the growth of modern science that arose in Western Europe, that we try to propagate in our universities and in private tutories, and The Scientific Revolution which was also essentially an European phenomenon, reminded me that our efforts at the establishment of a state of Scientific Literacy in Sri Lanka, have been in vain.

\section{References}

1. Beveridge WI. The Art of Scientific Investigation. Blackburn Press 2004.

2. Trusted J. The Logic of Scientific Inference: An Introduction. MacMillan 1979.

3. Willingham D. Trust Me, I'm a Scientist. Scientific American 2011.

4. Arseculeratne SN. Scientific Literacy: Its meaning and significance. Scientific World 1993; 1: 3-4.

5. Seeber GR. Un Nuevo esporozoario parasito del hombre. Dos casos encontrados en pólipos nasales. Tesis Doctor en Medicina Buenos Aires: 1900.

6. Kaluarachchi K, Sumathipala S, Eriyagama N, Atapattu D, Arseculeratne S. The identification of the natural habitat of Rhinosporidium seeberi with R. seeberi-specific in situ hybridization probes. Journal of Infectious Diseases \& Antimicrobial Agents 2008; 25: 25-32.

7. Arseculeratne SN, Mendoza L, William GH, Roderick JH. Topley \& Wilson's Medical Mycology. $10^{\text {th }}$ ed. London: Hodder Arnold; 2005

8. Herr RA, Ajello L, Taylor JW, Arseculeratne SN, Mendoza L. Phylogenetic Analysis of Rhinosporidium seeberi's 18S SmallSubunit Ribosomal DNA Groups This Pathogen among Members of the Protoctistan Mesomycetozoa Clade. Journal of Clinical Microbiology 1999, 37: 2750-54.

9. Fredricks DN, Jolley JA, Lepp PW, Kosek JC, Relman DA. Rhinosporidium seeberi: a human pathogen from a novel group of aquatic protistan parasites. Emerging infectious diseases 1991; 6: 273-82.

10. Ahluwalia KB. New interpretations in rhinosporidiosis, enigmatic disease of the last nine decades. Journal of submicroscopic Cytology \& Pathology 1992; 24: 440 - 43.

11. Ahluwalia KB, Sharma N, Kacker SK, Deka RC. Association of tapioca and chronic inflammation with rhinosporidiosis. Indian Journal of Otolaryngology and Head and Neck Surgery 1994; 46: 25-27.

12. Ahluwalia KB, Maheshwari N, Deka RC. Rhinosporidiosis: A Study That Resolves Etiologic Controversies. American Journal of Rhinology 1997; 11: 479-84.

13. Arseculeratne SN. Microcystis aeruginosa as the causative organism of rhinosporidiosis. Medical Mycology Journal 2000; 38: 39395.

14. Mendoza L, Herr RA, Ajello L. Causative Agent of Rhinosporidiosis. Journal of Clinical Microbiology 2001, 39: 413-15.

15. Medawar PB. Pluto's Republic. Oxford University Press 1982.

16. Bostock D. Aristotelian logic. Dictionary of the History of Science. London: Macmillan 1983.

17. Arseculeratne SN. Establishing a Tradition of Scientific Research in Sri Lanka. Second Professor ST Fernando Memorial Lecture 2002. 